\title{
ЛИТЕРАТУРОВЕДЕНИЕ
}

\author{
UDC 821.411.21
}

\section{Two Novels about the Information War in Yemen on the Eve of the Revolution of 2011}

\author{
M. N. Suvorov \\ St. Petersburg State University, \\ 7-9, Universitetskaya nab., St. Petersburg, 199034, Russian Federation
}

For citation: Suvorov M.N. Two Novels about the Information War in Yemen on the Eve of the Revolution of 2011. Vestnik of Saint Petersburg University. Asian and African Studies, 2019, vol. 11, issue 3, pp. 298-310. https://doi.org/10.21638/spbu13.2019.304

Around the mid-1990s, President Ali Abdullah Saleh's regime in Yemen began to realize the rapid decline in its popularity among the citizens. Total corruption, unemployment, unprecedented poverty growth, stagnation of all social services - all this turned the lives of thousands of Yemenis into daily struggle for survival. In the conditions of Yemeni population's growing discontent, one of the regime's instruments to keep control over the situation was the state media which implemented all means of propaganda to improve the image of the government in the eyes of the citizens. At the same time, printed and electronic publications of the opposition movements confronted the state media by revealing their lies and explaining to the readers the authoritarian and corrupt nature of the ruling regime. This information war which lasted until the fall of the regime in 2011 became the main theme of two Yemeni novels: War under the Skin (2010) by Ahmad Zayn (Zein) and Happy Land of Intrigues (2018) by Wajdī alAhdal. Ahmad Zayn concentrates on the inner world of his protagonist, a journalist working for the regime, and shows how he gradually comes to the understanding of his negative role in the information war. Wajdi al-Ahdal's protagonist, also a journalist working for the regime, discovers in his personal story all the methods, techniques, and tactics of this war.

Keywords: Arab literature, Yemen, corrupt media, information war, Ahmad Zein, Wajdi al-Ahdal.

In an Electric Literature website publication titled 12 Novels about the Power of Journalism: A reading list for a time when the media is more important and threatened than ever, one can read the following:

"Two things that are equally true at this point in time: journalism is especially necessary to the continued health of our nation's safety and civil rights, and journalism is in a moment of deep peril, with newsrooms being cut, advertising-based business models in

() Санкт-Петербургский государственный университет, 2019 
jeopardy, and political polarization wreaking its own form of havoc on the industry. Good journalism can give people a greater sense of the world around them; irresponsible journalism can stoke hatred or give cover to corrupt or immoral actions.

Needless to say, journalists and journalism have been the source of inspiration for many novelists. Some examine the institution itself, finding compelling narratives in the story of how news is reported. Others reiterate why the fourth estate matters; still others provide cautionary tales for why journalistic excesses can lead to a grim place. And another group finds the power in the lives of writers: how their job affects their home lives, their perceptions of the world, and their ability to function" [1].

Though the nation mentioned in the passage above seems to be American, the whole statement is true for any modern nation and especially for the Arab world with its social and political turmoil of the last decades, in which mass media has played and continues to play an important though ambiguous role.

As a pronounced theme in Arab literature, journalism appeared, as it seems, around the beginning of the 1960s - probably, for the first time in Najib Mahuuz's novel The Thief and the Dogs (1961). In the following years this theme in Arab literature developed into an independent genre, "journalism FASP", to use Shaeda Isani's definition" ${ }^{1}$.

It is noteworthy that starting from Najīb Mahfüz's novel, Arab writers' treating the theme of mass media has been focused on corrupt media and corrupt journalists. It is not easy to find in this literature - especially in that published in the last three decades journalist characters like "the roving reporter dashing off in pursuit of a hot scoop, the war correspondent reporting from the front at the peril of his life or the investigative journalist exposing injustice, corruption or wrongdoing" [2, p.9], which are quite typical for the journalism FASP in the West (see, for example [3-5]). There is no doubt that Arab writers' focus on corruption has reflected, first of all, the real state of affairs in the media of Arab countries, where thousands of well-paid professional liars were and are doing their best to create positive images of the ruling Arab regimes, most of which are profoundly authoritarian and corrupt.

By the time of the Arab Spring, the issue of corrupt media in Arab journalism FASP and in Arab literature in general became so prominent that in 2016 there appeared an Egyptian al-Sayyid al-Ṭanțāwīs study titled Corrupt Journalism in Egyptian and Arab Novel [6] ${ }^{2}$. In his book al-Ṭantāini discusses more than dozen literary works, most of them Egyptian, one Syrian and one Saudi. The majority of the works analyzed in the book were published in the years preceding the Arab Spring or during it. The authors of these works, who themselves are representatives of mass media, give the reader clear idea of what was going on in Arab media in the mentioned period.

${ }^{1}$ Explaining this definition, Shaeda Isani writes: "Fiction based on the creative conceit of generating plot dynamics within the context of a defined professional environment, if not a new literary device, became a sufficiently widespread phenomenon in popular literature in the latter half of the $20^{\text {th }}$ century to warrant special critical attention. Though critics isolated and identified various manifestations of the genre as 'Lawyer novels', 'Medical novels' or 'Technical thrillers', no attempt had been made towards establishing the genericity of such works of fiction until 1998 and 2000 when Michel Petit published two founding texts in which he isolated and defined a new literary genre, fiction à substrat professionnel or FASP [2, p. 2]. In keeping with a certain literary tradition in English, the term is not translated and remains FASP as, for example, in the case with roman noir, roman policier, roman à clé genre, etc. [2, p. 14].

${ }^{2}$ All quotations of Russian and Arabic sources, as well as the names of Arabic books (with exception of The Thief and the Dogs and Mountain Boats), are given in the article in the author's translation. 
The present study is intended to expand al-Ṭanțāwìs analysis by introducing two novels written by Yemeni authors and devoted to corrupt journalism and its role in the information war in Yemen in the decade preceding the Arab Spring. These two novels are War under the Skin (2010) by Ahmad Zayn (Zein) and Happy Land of Intrigues (2018) by Wajdī al-Ahdal [7-8]. Both writers are listed among the leading Yemeni novelists: Ahmad Zayn is the author of four novels, Wajdi al-Ahdal - of five. At the same time, both writers know the work of media "from inside": Ahmad Zayn works in Saudi newspaper al-Hayāt, Wajdī al-Ahdal heads the publishing house of Yemeni magazine al-Thaqā $\mathrm{fa}^{3}$.

Before analyzing these two novels, it would be appropriate to say a few words about the sociopolitical situation in Yemen which produced the main idea of these novels and in which the action of these novels develops.

Around the mid-1990s, President Ali Abdullah Saleh's regime in Yemen, which is often characterized by experts as "military-tribal", "family", and "kleptocratic" oligarchy, began to realize the rapid decline in its popularity among the citizens. Total corruption, unemployment, unprecedented poverty growth, stagnation of all social services - all this turned the lives of thousands of Yemenis into daily struggle for survival. The Unification of Yemen's North and South into a single state, which in 1990 was carried out by this regime and became an almost sacred symbol of its greatness, in the situation of continuing deterioration of living conditions began to lose its sacred meaning.

Sergei Serebrov, an expert in Yemeni politics, wrote: "In 2005, the proportion of citizens with an income of less than two dollars a day was estimated by the UN development Organization at $46.6 \%$. Peaceful demonstrations against the economic policies dictated by the IMF and IBRD posed a major threat to the regime in the years 2005-2006 when the last presidential elections before the revolution were held. In parallel with the unrest in the main cities, inter-tribal conflicts were also on the rise, some of which took the form of clashes with government forces. The regime relied on the exploitation of the still alive ancient archetype of Yemenis' political consciousness - a dichotomy between the culture of cities (hadar) and the culture of qaba' $i l(\mathrm{badw})$. Conflicts were intended to deter other conflicts. The tribalism's offensive on public relations in the cities terrified the urban population" [13, p.3].

In the conditions of Yemeni population's growing discontent, one of the regime's instruments to keep control over the situation was the state media which implemented all means of propaganda to improve the image of the government in the eyes of the citizens. At the same time, printed and electronic publications of the opposition movements confronted the state media by revealing their lies and explaining to the readers the authoritarian and corrupt nature of the ruling regime. As the socio-political atmosphere in the country became more and more tense (the conflict between the government and the

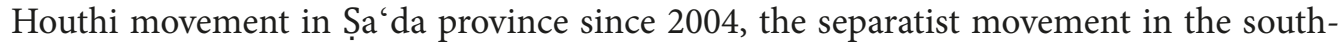
ern part of Yemen since 2007), the confrontation between the regime and the opposition in mass media turned into a real information war, which was full of loud revelations and shameless misinformation, bribery and betrayal, lawlessness and violence, including physical elimination of the opponents. It was this information war that became the main theme of the two novels.

${ }^{3}$ About these two writers' previous works see [9, p. 258-260, 276-290; 10; 11; 12]. 
War under the Skin is written in a so-called "cinematic" manner, which is inherent to Ahmad Zayn. Its essence lies in the fact that the text of the work is made up of a mosaic of disparate scenes (or "frames") in which things are not so much called by their names as they are described. The author arranges these frames in such a way that their interaction causes the process of induction of meanings. At the same time, a consistent story about the events is almost absent, the intrigue may also be absent or not obvious.

To a greater or lesser extent, Ahmad Zayn used this style in all his works which made them, according to some critics, very difficult to perceive. Thus, Yemeni writer and critic Muḥammad Aḥmad 'Uthmmān, while reviewing Aḥmad Zayn's first novel Confirmation of the Status (Tașhīh waḍ', 2004) with its mosaic narrative, with "tacitly" written out scraps of memories of different characters, with these characters' feelings relating to an indefinite time, with scattered and not clearly localized in time and space episodes and scenes, concluded that all of the above "suggests that the main theme of this text is the text itself" [9, p. 260]. "This text, - he writes, - exists only when the reader is in it, returns to it, lives in its particular aesthetics shaped by the interaction of the language and the countless tiny details into which the narrative disintegrates" [9, p. 260]. The novel War under the Skin is fully consistent with what the critic wrote, so we will consider here only those aspects that relate to the content of the novel and to its main theme.

The narrative in the novel is in third person. The protagonist Qays, a journalist in a governmental newspaper in Sanaa, tries to write a study on akhdām, the lowest stratum in Yemeni society, Yemeni "untouchables", whom the author calls simply "marginalized" (muhammashiun). Qays received an order for this study privately from a Western human rights organization. In the course of work, Qays communicates with Zahrā', a young woman of the akhdām stratum, who has played a role in a semi-documentary film about this stratum. Episodes of this film constantly emerge in his memory; in the text of the novel they are marked by the expanded right and left margins. Besides, Qays reads a novel Way of Azraqites devoted to the life of akhdam. The protagonist of this novel, old Shammāl, reflects on the participation of his fellows akhdām in Yemeni revolution of 1962 and in the subsequent Civil war (1962-1970). He feels bitter disappointment from the fact that $a \underline{k h} d \bar{a} m$ 's hopes for a better life after the Revolution haven't come true. A constant interlocutor of Shammāl is one of the military leaders of the Revolution, whose services to the Republic have long been forgotten by all. The man in the novel has no name; the author calls him "the holder of medals" (șähib al-nayāshinn). Fragments of this novel, read by Qays, are given in italics.

Qays communicates with many people of his generation: with his friend Țāriq, with journalists Shāhir and 'Alyā, with painter Ṭalāl, with a German anthropologist. He also communicates with older people: with his own decrepit father and a man whom the author calls "the sixty years old" (al-sittīnì). All characters (including Shammāl and "the holder of medals") speak about the past and present of the country, thus forming in the novel a picture of life in Yemen in the second half of the $20^{\text {th }}-$ early $21^{\text {st }}$ century.

Some of them, especially Shāhir and 'Alyā, sharply criticize the current situation in the country, which leads Qays into confusion. After all, it is against people like Shāhir and 'Alyā that the ideological mentor of Qays, the editor-in-chief of his newspaper, a devoted supporter of the ruling regime, is waging irreconcilable information war. 


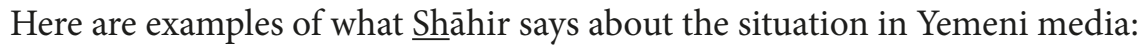

"...He said that there are more newspapers in Yemen after the Unification than those who can read. He puzzled them (Qays and 'Alyā. - M. S.) by his idea of creating his own newspaper. He explained that he can no longer work in the newspaper which changes its idols four times a month and every week embraces new ideals» [7, p. 18-19].

"They've got in our hair with that freedom of speech. From morning till night there is freedom of speech. It seems to be instead of bread already. However, today everything has turned upside down... They exclude you from profession... They close in your face all the ways for further existence. Of course, if you have not been detained outdoors in broad daylight while going somewhere with friends. Or if they haven't broken into your house, where you were playing with your kids, and taken you away. And recently they began to listen to telephone conversations and to use them as evidence" [7, p. 48].

Qays is reluctant to believe in what he is told about: in anti-government demonstrations in South Yemeni cities, in attacks on independent journalists, in kidnapping representatives of the opposition media. All these facts contradict what Qays himself writes in his newspaper. However, as a result of this communication and of his gradual penetration into the issue of a khdam, Qays comes to an understanding that the Unification of Yemen in its symbolic meaning is a simulacrum. "Under the skin" of Yemen there is a total war: between the regime and the opposition, between North Yemenis and South Yemenis, between supporters of the archaic and supporters of modernization. Qays understands that he himself, while enthusiastically carrying out the instructions of the editor-in-chief, simply participated in propaganda for which the editor-in-chief received large sums of money from the regime.

In a state of mental crisis, Qays realizes that he is unable to complete his study on $a \underline{k h} d \bar{a} m$. Here is how it is described in the novel:

"He stopped writing in order to revise what he had already written. And he was unable to believe his eyes. Confused, he felt himself weak. The text was meaningless, incoherent. Just a mess of words. How could this happen? The marginalized mingled with the demonstrators in Aden and Mukalla, who in their turn merged with the events in Sa'da. Shammāl and the holder of medals in the novel intertwined with Zahrā', the little boy, and the dead body in the film. Way of Azraqites merged with the inn and with those wretched hovels filled with stench, flies, children's shit, and menstrual blood. He was unwilling to write. He realized he couldn't go on" [7, p. 156].

"The problem is not in the Unification, neither in separatism, - Qays muses in the finale of the novel, - but in the fact that our situation is like a quagmire that sucks everyone in and absorbs everyone forever. This is a country that raises slogans of statehood, democracy, the rule of law, but in fact is nothing more than a self-righteous tribe which has not learned to meet the spirit of the time and the needs of man" [7, p. 191].

In a review of the novel War under the Skin, popular Kuwaiti novelist Tālib al-Rifā' $\overline{1}$ wrote:

“Ahmad Zayn's novel War under the Skin published in 2010 by Dār al-adāb publishing house looks one hundred percent Yemeni: it reveals and cleanses the Yemeni festering wound - the external unity of the country with its internal disunity, lurking 'under the skin'. However, the actions and logic of the characters in the novel, their disappointments and their change of beliefs - all this is typical for many other Arab countries in which the media day and night broadcast about the unity, the well-being of the citizens, and the decent life, while the realities of life demonstrate quite the opposite" [14]. 
Wajdī al-Ahdal's novel Happy Land of Intrigues - in contrast to War under the Skin is written in a manner that makes the outlining of its plot not very complicated. Happy Land of Intrigues is a dynamic narrative of a semi-detective nature, which is very characteristic of Wajdī al-Ahdal's writings, and has a consistent composition and a pronounced intrigue.

The text of the novel is divided into 65 chapters, which are named after days of the week: Monday, Tuesday, Wednesday, Thursday, Friday, Saturday, Sunday, Monday, Tuesday and so on. The given numbers of chapters follow curiously in descending order from 64 to 0 . The action in the novel thus takes about nine and a half weeks ${ }^{4}$. This action takes place in 2002, as is indicated by the result of the final match in the world Cup, which the protagonist watches on TV in the first (not by numeration) chapter: Brazil's victory over Germany.

The protagonist Muțahhar Faḍl is an experienced journalist working in a pro-regime newspaper $a l-\underline{S h} a^{\prime} b$ in Sanaa. He is the narrator in the novel.

The story begins when Riyād al-Kayyād, the editor-in-chief of the newspaper, sends Muțahhar on a business trip to al-Hudayda province with the purpose of journalistic coverage of a scandalous incident ${ }^{5}$. A local sheikh Bakrī Hasan, a prominent member of the ruling party and one of the tribal leaders on whom the regime relies, was detained by the police on suspicion of raping an eight-year-old girl.

The reader learns that Mutahhar is a son of a prominent leftist politician, already deceased. Since the father used to be repeatedly imprisoned, the childhood of Mutahhar and his six brothers passed in terrible poverty. For this reason, Mutahhar does not have any good feelings for the memory of his father.

Having arrived at the site, the village of Bāb al-Manjal, Muțahhar gets access to the injured girl, whose name is Jalila, and makes sound-recording of her story about the incident. Then he sends the material to the newspaper, but soon receives a telephone call from Riyād al-Kayyād, who gives him instruction to distort the girl's story before it is published:

"He told me frankly, - Muțahhar tells us, - that I must edit the story in such a way that the identity of the perpetrator remained unknown. He insisted that the story to be published should present the sheikh in the best light and that our task in our motherland's sake is to change the negative public opinion about the sheikh to the opposite, to sympathy for him as a victim of an unfair accusation" [8, p. 25].

Mutahhar follows the instruction of his chief, and from that moment all his activities turn into information war against opposition journalists, human rights activists and a few decent representatives of the law enforcement bodies. He wages this war on the pages of his newspaper and on Facebook. The reader realizes that Mutahhar doesn't care about the truth, he simply writes for money what the editor-in-chief wants him to write. His publications about people who strive for Bakrī Hasan's punishment contain such shameless lies that even his mercantile wife, who remained with their children in Sanaa, cannot stand it. In a telephone conversation with Muțahhar she says scornfully: "Come on, give them your ass for money!" [8, p. 89]. Since the articles about the rape case attract a lot of public attention, Mutahhar's name becomes more and more recognizable in the reading circles.

4 This may well be an allusion to Adrian Lyne's Nine 1/2 Weeks (1986): in al-Ahdal's earlier works, very post-modernistic in their nature, tricks of such an aimless kind were not unusual.

5 The family name al-Kayyād means in Arabic "intriguer"; giving the characters talking names is also not unusual for Wajdì al-Ahdal. 
Corrupt police let Bakrī Hasan free, but the case against him is not closed. In order to ensure that the journalistic coverage of the case is "correct" in terms of the regime, Mutahhar, following the instructions of the editor-in-chief, settles in a rented apartment in the seaside city of al-Hudayda, the administrative center of the province. In addition to large sums of money, expensive alcohol drinks and cigarettes, which Mutahhar receives from the regime as a payment for his services, there are other "bonuses". Sheikh Bakrī Hasan gives Muțahhar "for temporary use" his concubine, 15-year-old beauty Munā, and Muțahhar falls in love with her. He feels uncomfortable with the idea that Munā is property of the sheikh. Nevertheless, they have a great time enjoying each other, local cuisine and the sea.

After some time, Munā leaves Muțahhar because Bakrī Hasan ostensibly needs her services in the preparation of his sister's wedding. Riyād al-Kayyād gives Muțahhar instruction to establish close relationship with Russian doctor Tatiana who conducted a medical examination of Jalila in the hospital of the regional center al-Jurüm. Having agreed with Tatiana about interview, Mutahhar meets her in one of the seaside clubs of al-Hudayda, where she likes to spend time on the weekends. During the meeting they feel sympathy for each other, and Mutahhar - following the plan of the editor-in-chief - offers Tatiana a trip to the island Qamarān in the Red Sea. Tatiana agrees and they arrange the date of the trip.

The trip starts with bad news. Tatiana tells Mutahhar that the day before a seven-yearold girl Muhsina had died in the hospital of al-Jurüm after she had been brutally raped by her adult husband. This story overshadows their romantic trip to the island. However, on their return to al-Hudayda they spend night in one bed in Muțahhar's apartment. The next day Tatiana unexpectedly receives a message from the hospital administration, informing her that she has been given an unscheduled leave. She remains in al-Hudayda with Muțahhar. As it will become clear later, this was arranged in order that Tatiana, who was the main witness of Muhsina's death, never come back to the hospital.

Thanks to human rights activist Salām Mahdī, one of the main opponents of Muțahhar, Muhsina’s death is widely publicized. Yemeni regime comes under fire from international human rights organizations demanding the prohibition of early marriage. Muțahhar along with correspondents of other pro-regime newspapers arrives at al-Jurūm, where they all become participants in the staging of a "performance" with a girl looking like the late Muhsina. This "performance" is intended to convince the public that Muhsina is alive and well. Muhsina's father, who married off his seven-year-old daughter out of greed, immediately accuses Salām Mahdī of slander and submits the application to the court. The human rights activist soon finds herself in prison.

On his return from al-Jurūm to al-Ḥudayda, Muțahhar does not find Tatiana in his apartment. His fellow lawyer tells him that Tatiana has been expelled from the country on the accusation of illegal operations to restore virginity. All results of her medical examinations are immediately recognized as not valid in any juridical procedures.

Very soon sheikh Bakrī Hasan gives Muțahhar a female servant instead of Munā a young Khātima ${ }^{6}$. Initially she seems to Muțahhar totally clogged, dumb creature, but soon there appears candor between them, and they become lovers. It is Khātima who tells

${ }^{6}$ Khātima is another talking name in the novel. In Arabic it means "end" and is sometimes given to a newborn girl if the parents don't want to have more daughters or more children at all. But in the novel Khātima puts an end to Muțahhar's career and prosperity. 
Muțahhar about many girls who became victims of Bakrī Ḥasan's pedophilia. Khātima herself at the age of eight was married to her cousin, but Bakrī Hasan forced her husband to divorce her and took Khātima to himself.

The information war waged by Mutahhar comes to its culmination when he participates in Riyād al-Kayyād's plan for raider capture of an opposition newspaper al-Niḍāl, being published in al-Hudayda. In the late evening, security forces arrest all the members of the editorial staff of the newspaper, and their place is being taken by a team which was built in advance by Riyād al-Kayyād. Muțahhar takes place of the arrested editor-in-chief Ghālib Zubeyța, who used to be Muțahhar's constant opponent.

Muțahhar's rejoicing, however, quickly turns into melancholy. The brutal forceful seizure of the editorial office has made an unpleasant impression on him and for the first time made him think about the moral aspect of his work. He gets especially sad when in a bookstore, beside a pile of unsold issues of $\mathrm{Al}$-Nidial, he notices among other books a collection of articles published ten years ago for the anniversary of his father. Reflecting on his dislike for his father, Muțahhar understands that the reason for this dislike was not only the poor childhood. Perhaps, at a greater extent, this dislike was generated by jealousy of the son to the father's popularity among his associates, which didn't affect the son. It was this jealousy that led Mutahhar - as a kind of revenge - to choose a path in life opposite to his father's path.

Mutahhar recalls another episode of his life which also predetermined his path. His would-be father-in-law, a wealthy man, while looking at poorly dressed Muțahhar during their first meeting, said: "I want to marry my daughter to a man of the state. Are you ready to become a man of the state?" [8, p.251]. Mutahar replied in the affirmative.

Mutahhar's depression is exacerbated by the news of the brutal murder of Sāmī Qāsim, a journalist who was one of Muțahhar's main opponents in the case of Jalila. Meanwhile, a new judge in al-Jurūm court (the previous one was dismissed not without involvement of Muțahhar, who wrote a defamatory article about him) offers sheikh Bakrī Hasan and Jalila's grandfather to resolve the matter amicably in a traditional Yemeni way: to marry the raped girl to the rapist. The sheikh gladly agrees, but the girl's grandfather refuses. After a while, Bakrī Hasan and his henchmen break into the house of Jalīla's grandfather and, threatening him with murder, demand Jalila to become sheikh's wife. The grandfather reports the incident to the prosecutor's office and to the human rights activist Salām Mahdī, who has been released from prison by that time. Thanks to the latter, the news appears in all opposition newspapers.

On the background of his doldrums, Muțahhar is making friends with Fathiya, an imposer in the editorial staff of al-Nid̄al. In her intention to win Muțahhar's heart, the young woman behaves in a candid manner. However, after learning by chance that Mutahhar lives with Khātima, Fathiya retreats.

Suddenly, Khātima leaves Muțahhar's apartment. All his attempts to find her lead to nothing. Fathiya takes advantage of the situation and conquers Mutahhar - not only with the help of her female charm, but also by striking him with the wealth of her inner world. Mutahhar understands that Fathiya is the woman he needs, his other half.

Love affair with Fathiya saves Muțahhar from depression. At this very time, the editorial staff of al-Nid̄al receives an important task from the government. The corresponding episode in the novel well demonstrates the nature of the work of the pro-regime periodicals: 
"The UN human rights Council in Geneva, - Mutahhar tells us, - has issued a decree that the marriage of young girls in Yemen is a crime and that the perpetrators of this crime will be punished in accordance with the law.

I received a call from Riyād al-Kayyād, who demanded that we prepare a file of materials on the achievements of Yemeni government in eradicating the practice of early marriage. The materials were to be published in $a l-\underline{S h} a^{\prime} b$. He said that the young employees who work with me are well aware of the corresponding situation on the Red Sea coast of Yemen, and all of them must give themselves to collecting these materials. He also ordered me to stay in the office until the morning so that I could provide any additional material on the subject, be such required. I declared a state of emergency to the staff, and we began to squeeze out our brains in order to invent those achievements" [8, p. 283].

The day after the imposition of this "state of emergency" Mutahhar receives a crushing blow. A formerly leftist newspaper al-Sanäbil al-Hamrā', in which Muțahhar's father used to publish his articles and which at the moment was headed by Ghālib Zubeyța, recently released from prison, posted on the first page of its new issue a catchy title: "Girl Khātima tells about her escape from the apartment of a prominent journalist who used her as a sex slave" [8, p. 286]. The article was accompanied by two photographs: a photograph of Khātima with a caption "Girl Khātima, a victim of underage sex slave trade in Yemen", and a photograph of Muțahhar with a caption "Human monster Muțahhar Faḍl, the journalist who bought Khātima in order to use her as a servant and as a tool for forbidden pleasures" [8, p.286]. In the story of Khātima, a girl Munā was mentioned who had also been a sexual slave of this popular journalist.

The article appeared to be for Mutahhar that terrible blow which he often gave other people but had never received himself. On the same day his wife called him and demanded divorce. At first, Muțahhar's understanding of his social and professional collapse almost deprives him of reason, but in the end makes him find the only possible way out of the situation. He decides to return to the capital and then hide for some time with his rural relatives. His tribal roots revive in his soul at this moment, and he decides to kill Ghālib Zubeyta - as the tribesmen always do when they take revenge for insulted honor.

Fathiya, unable to hold back tears, escorts Mutahhar to the parking of intercity taxi. Muțahhar gets into a taxi, the car gets filled with passengers and starts. In the town of Bājil, the last settlement in the coastal part of Yemen before climbing into its mountainous part, the taxi makes a stop. And here Wajdì al-Ahdal adds to his narrative a mystical element of a kind that can be found in many of his works:

"An old beggar woman came up. Nobody gave her anything. Even I did not reach into my pocket for money, feeling fear. The woman had eyes of the kind I'd never seen in my life. They were yellow, and it seemed that they rotate in a spiral and can pull inside anything. If someone had told me about this, I would not have believed it, but at the moment I experienced it for myself. It wasn't an artificial fear that we feel when we watch a horror movie. It was the natural animal fear that enters your heart and makes you feel an irresistible urge to urinate. Suddenly the old woman approached her face to the driver and said, 'Don't go this night'. The driver calmly replied, 'What night, aunty? It's daytime.' The old woman said, 'Have you heard of the ghost of the old man who appears once a year? He'll be here tonight'. The driver swallowed his saliva and replied, 'I've heard'. She pointed to the East, 'He will appear after Bāb al-Nāqa pass. Last year a lot of people were killed because of him'. The driver said, 'I don't care. Even if he appears 
on my way, I'll hit him and proceed'. He laughed hysterically and gave the old woman a hundred riyals" [8, p. 299].

After Bāb al-Nāqa pass the taxi drove into a thunderstorm zone. The earth was shrouded in darkness, rainwater was streaming down the mountains with roar.

"Dangerous turns went one after another, the road meandered like a snake. Lightning flashed, and in its light there flashed a human figure standing in front of us on the road. One of the passengers cried out, 'It's the old man!' The driver switched low beam to high, and we saw him: a red shaggy beard and burning with anger eyes, staring at us. The driver instinctively hit the brakes, and the next moment the old man shifted from our lane to the opposite. The driver released the brakes, exhaling with relief, but immediately a loaded truck showed up from behind the turn, as speedy as if it were falling down the mountain. In an attempt to get around the old man the truck took to our lane. The driver saw us when we were face to face. The blow - and we soared in the air like birds" [8, p. 300].

This passage ends the penultimate chapter of the novel.

In the last chapter, which has no name, but only a number - zero, Mutahhar, having got out through the keyhole from a closed room filled with snakes, lizards and poisonous insects, meets Fathiya. She tells him about what he did not know in his life and what happened after his death. Much of what Fathiya tells him seems absurd - but it is certainly the will of Wajdi al-Ahdal to tell the reader that any absurdity is possible in Yemen ${ }^{7}$.

Riyād al-Kayyād took the post of Minister. Khātima gave birth to Muțahhar's son and married the lawyer, Muțahhar's friend. Muțahhar's widow married Ghālib Zubeyța. Ghālib Zubeyța, who became an important figure in the opposition movement, was originally an agent working for the regime. That is why he was appointed the editor-in-chief of the newspaper al-Sanābil al-Hamrā'. The scandalous article about Muțahhar and Khātima was published by him on the instructions of the authorities: they needed a scandal that could distract the public from sheikh Bakrī Hasan's case. The scandal was promoted in the press even after Mutahhar's death: some wrote that his death in a car accident was a fiction, and that in reality the authorities gave him an opportunity to go to Germany and live comfortably there. Under the cover of this scandal, the court in al-Jurum ruled that it was Jalīla who raped sheikh Bakrī Hasan, not the other way around, and sentenced the girl to detention in a correctional facility for juvenile offenders. When Jalila was released from the reformatory, Bakrī Hasan again requested her to be his wife, but was again refused. Then his henchmen attacked the girl when she was playing on the street with two female relatives, four and six years old, and cruelly beat all three.

Having learned this news, Mutahhar, accompanied by Fathiya, goes to the hospital where the girls are cured. He wants to ask Jalila for forgiveness for his vile deeds. However, by the time they arrive, Jalila has already died.

The final passage of the novel reads:

"The Peugeot's car finished tumbling and fell silent, lying upside down on the bottom of a watercourse. The flow of rainwater, like the mother's womb, began to gently lull us to sleep, singing a quiet lullaby so that we could sleep peacefully" [8, p. 310].

7 Portraying Yemeni every-day life as total absurdity is the main feature of al-Ahdal's first novel Mountain Boats (Qawārib jabaliyya, 2002), which created a considerable amount of controversy in Yemen. About this novel see [9, p. 281-290]. 
There is obvious difference between the two novels in what Shaeda Isani calls the "degree of FASPness", i.e. the degree "to which journalism and journalists are integrated into plot and character construction" [2, p. 4]. Isani writes:

"Paul Steinle in Print (and Video) to Screen: Journalism in motion pictures of the 1990s (2000) classifies journalism-related fiction into four categories: fiction in which journalists are the key characters, fiction in which journalism itself is the predominant focus, fiction in which characters are cast as journalist but their professions reflect little on the plot and finally, fiction in which journalists are merely transitional devices advancing the plot. $<\ldots>$ To meet the substrat professionnel criteria, the professional environment of the work of fiction must constitute the creative pivot of characterization, plot and denouement..." [2, p. 4-5].

Undoubtedly, Happy Land of Intrigues meets the mentioned substrat professionnel criteria and may be classified in both the first and the second categories of Paul Steinle's scheme. The work of a corrupt journalist in the realms of information war is presented in this novel in all details. A significant part of Wajdī al-Ahdal's narration is devoted to the description of professional relations 'inside' the corrupt media, as well as to the description of all the methods, techniques, and tactics implemented by this media in the information war, including even the texts created by the warring parties on their personal Facebook pages. The objectivity of the writer's depiction of these methods, techniques and tactics is beyond doubt: they all are recorded in the materials of Yemeni press stored on the Internet. In this respect, Happy Land of Intrigues is a sample of the "new age" journalism FASP $^{8}$.

As for War under the Skin, the novel may be classified in the third category. Due to Ahmad Zayn's "cinematic" manner of writing, the work of the journalist and the details of the information war emerge only in the few fragmentary messages of different characters. The reader does not know what topics the protagonist covers in his newspaper, what exactly he writes, who are his opponents, how his interaction with the editor-in-chief takes place. Obviously, these details do not constitute the main interest for the author of the novel. Much more attention Ahmad Zayn pays to the inner world of his hero, in which the reader can observe a gradual change - primarily as a result of the protagonist's growing awareness of his own negative role in this information war. Of course, it may seem strange that before the beginning of his study on akhdām Qays did not doubt the correctness and sincerity of the political position of his newspaper. But awakening, as we know, does not come to all in one time.

Finally, everything that the reader finds in these two novels - the characters and destinies of the "information war fighters", the tricky style of mass media's work, the relations of "patronage in exchange for services" between the authoritarian regime and the mass media, the general atmosphere of lies and absurdity, etc. - is very similar to what can be found in such Egyptian and Syrian novels as Lowlife (2008) by Muhammad Ghazlān, April 26 (2009) by Khālid Ismāīl, Maspero (2010) and Journalist (2012) by Nașr Ra'fat, Tunnel of Dishonor (2014) by Samīra al-Masālima, Ayyash (2017) by Aḥmad Majdī Hammām [15-

${ }^{8}$ Shaeda Isani writes: "The sweeping technological and social changes brought about with the advent of the internet has so transformed the practices and ethos of the profession that it would not be inappropriate to evoke the turn of the century as a demarcation between two journalistic cultures" [2, p. 3]. 
20]. However, what distinguishes War under the Skin and Happy Land of Intrigues from other Arab journalism FASP is the atmosphere of unparalleled socio-political violence in which the action takes place. This violence, inherent in Yemeni fiction in general, is just a reflection of what happens in reality in Yemeni everyday life.

\section{References}

1. 12 Novels about the Power of Journalism: A reading list for a time when the media is more important and threatened than ever. Available at: https://electricliterature.com/12-novels-about-the-power-of-journalism/ (accessed: 24.05.2019).

2. Isani, Shaeda. Journalism FASP and fictional representations of journalists in popular contemporary literature. Available at: http://journals.openedition.org/ilcea/251 (accessed: 24.05.2019).

3. Good, Howard. Acquainted with the Night. The Image of Journalists in American Fiction, 1890-1930. Metuchen, N. J., Scarecrow Press, 1986. 130 p.

4. Ehrlich, Matthew C. and Saltzman, Joe. The Image of Journalist in Popular Culture. University of Illinois Press, 2015. 256 p.

5. Lonsdale, Sarah. The Journalist in British Fiction and Film. Bloomsbury Academic, 2016. 296 p.

6. al-Ṭantāīì, al-Sayyid. Corrupt journalism in Egyptian and Arab novel. Cairo, Dār Kutubkhāana, 2016. 176 p. (In Arabic)

7. Zayn, Ahmad. War under the skin. Beirut, Dār al-adāb, 2010. 192 p. (In Arabic)

8. al-Ahdal, Wajdī. Happy land of intrigues. Beirut, Dār Nawfal, 2018. 310 p. (In Arabic)

9. Suvorov M. N. Fiction prose in Yemen (1940 - mid 2000s). St. Petersburg, OOO "Studiia NP-print", 2010. 359 p. (In Russian)

10. Suvorov M.N. New manners of writing in Yemeni prose of the 1990-2000s. Vestnik of Sankt-Petersburg University. Ser. 9, 2010, issue 2, pp. 185-193. (In Russian)

11. Suvorov M.N. Postmodernist parody novels of Yemeni writer Wajdī al-Ahdal. Vestnik of SanktPetersburg University. Ser. 9, 2010, issue 3, pp. 289-296. (In Russian)

12. Suvorov M.N. "Big" proze in Iemen it the second half of the first decade of $21^{\text {st }}$ century. Vestnik of Sankt-Petersburg University. Ser. 13, 2010, issue 4, pp. 83-91. (In Russian)

13. Serebrov S.N. Yemen: national dialogue and the problem of Southern separatism. Otsenki $i$ idei. B'ulleten', vol. 1, no. 5. Moscow, IV RAN, 2014. 22 p. (In Russian)

14. al-Rifā' $\overline{1}$, Țālib. War under the skin... war on the ground of reality. Available at: http://archive.aawsat. com/details.asp?issueno=11700\&article=597126.XJn1XskzZdgwq1 (accessed: 24.05.2019). (In Arabic)

15. Ghazlān, Muhammad. Lowlife. Cairo, Dār Uktub li-l-nashr wa-l-tawzī‘, 2008. 254 p. (In Arabic)

16. Ismā̄̄il, Khālid. April 26. Cairo, Dār Fikra li-l-nashr wa-l-tawzī‘, 2009. 190 p. (In Arabic)

17. Ra'fat, Nașr. Maspero. Cairo, Maktabat Madbūlī, 2010. 372 p. (In Arabic)

18. Ra’fat, Nașr. Journalist. Cairo, Markaz al-hadūāa al-'arabiyya, 2012. 383 p. (In Arabic)

19. al-Masālima, Samīra. Tunnel of dishonor. Beirut, Dār Ḍifäf, 2014. 167 p. (In Arabic)

20. Hammām, Aḥmad Majdī. Ayyash. Beirut, Dār al-Sāqī, 2017. 208 p. (In Arabic)

Received: April 8, 2019

Accepted: June 17, 2019

Author's information:

Mikhail N.Suvorov — Dr. Sci. (Philology), Professor; soumike@mail.ru 


\title{
Два романа об информационной войне в Йемене в первом десятилетии XX века
}

\author{
М. Н. Суворов
}

Санкт-Петербургский государственный университет, Российская Федерация, 199034, Санкт-Петербург, Университетская наб., 7-9

Для цитирования: Suvorov M. N. Two Novels about the Information War in Yemen on the Eve of the Revolution of 2011 // Вестник Санкт-Петербургского университета. Востоковедение и африканистика. 2019. Т. 11. Вып. 3. С. 298-310. https://doi.org/10.21638/spbu13.2019.304

Примерно с середины 1990-х годов правивший в Йемене режим президента Али Абдаллаха Салеха начал осознавать быстрое снижение своей популярности среди населения. Тотальная коррупция, безработица, беспрецедентный рост бедности, стагнация всех социальных служб - все это превращало жизнь тысяч йеменцев в ежедневную борьбу за выживание. Одним из инструментов удержания контроля над ситуацией в условиях роста недовольства населения для йеменского режима стали государственные СМИ, которые с помощью лживой пропаганды всячески старались улучшить имидж власти в глазах граждан. Между тем печатные и электронные издания оппозиционных движений оказывали противодействие государственным СМИ, вскрывая их лживость и объясняя читателям авторитарную, коррупционную сущность правящего режима. Эта информационная война, которая продолжалась вплоть до падения режима в 2011 г., стала главной темой двух йеменских романов: «Война под кожей» (2010) Ахмеда Зейна и «Счастливая страна козней» (2018) Ваджди аль-Ахдаля. Романы отличаются между собой степенью отражения в них реалий журналистской деятельности. Ахмед Зейн сосредоточен на внутреннем мире своего героя, журналиста, обслуживающего правящий режим. Автор показывает, как журналист постепенно приходит к осознанию своей негативной роли в этой информационной войне. Из-за «кинематографической» манеры письма Ахмеда Зейна конкретные детали этой войны всплывают в романе в немногих обрывочных сообщениях разных персонажей. Главный герой романа журналист Ваджди аль-Ахдаля, также работающий на правящий режим, в своей личной истории раскрывает методы, технику и тактику этой войны. Реалии журналистской деятельности представлены в романе очень детально: от описания профессиональных отношений «внутри» коррумпированных СМИ до цитирования текстов, создаваемых противоборствующими сторонами на их личных страницах в сети «Фейсбук».

Ключевые слова: арабская литература, Йемен, коррумпированные СМИ, информационная война, Ахмед Зейн, Ваджди аль-Ахдаль.

Статья поступила в редакцию 8 апреля 2019 г., рекомендована к печати 17 июня 2019 г.

Контактная информация:

Суворов Михаил Николаевич — д-р филол. наук, проф.; soumike@mail.ru 